\title{
AGONIA NO BAIRRO ITACORUBI/FLORIANÓPOLIS/SC: CRÔNICAS DE UMA MORTE ANUNCIADA
}

\author{
Vera Lúcia Nehls Dias ${ }^{1}$ \\ Maria Carolina Soares ${ }^{2}$
}

\begin{abstract}
Resumo: Este estudo visa conhecer as alterações de zoneamento no bairro Itacorubi, uma vez que foi o bairro do Distrito Sede que mais sofreu alterações no zoneamento desde a aprovação da Lei 001/1997 até $2010^{3}$. Um dos objetivos desta pesquisa é demonstrar que as alterações propostas no Plano Diretor isoladamente, apesar de legais, podem influenciar e prejudicar a globalidade do Plano. Outro objetivo busca constatar os desdobramentos das ações políticas no traçado urbano da cidade, que privilegia alguns poucos em detrimento de usos públicos e de maior interesse da sociedade local. A metodologia adotada combinou técnicas de pesquisa em arquivos - em especial os arquivos da câmara municipal de Florianópolis e levantamento de campo no bairro, além de análises do mapeamento das alterações e; revisão bibliográfica sobre os Planos Diretores, políticas públicas, planejamento urbano e legislação urbana.
\end{abstract}

Palavras-chave: Zoneamento; Alteração da Lei do Plano Diretor; Bairro Itacorubi; Florianópolis - SC

\section{AGONY IN THE ITACORUBI NEIGHBORHOOD/ FLORIANÓPOLIS / SC: CHRONICLES OF AN ANNOUNCED DEATH}

\begin{abstract}
This study aims to know the particularities of zoning changes in the Itacorubi neighborhood, since it was the district of the Headquarters District that suffered the most zoning changes since the approval of Law 001/1997 until 2010. One of the objectives of this research is to demonstrate that the changes proposals in the Master Plan alone, although legal, can influence and harm the overall Plan. Another objective is to demonstrate the unfolding of political actions in the urban layout of the city, which privileges a few to the detriment of public uses and greater interest of the local society. The methodology adopted combined archival research techniques - especially the archives of Florianópolis city hall and field survey in the neighborhood, as well as analysis of the mapping of changes and; bibliographic review on the Master Plans, public policies, urban planning and urban legislation.
\end{abstract}

Keywords: Zoning; Amendment of the master Plan Law Modification; Itacorubi neighborhood; Florianópolis - SC

\footnotetext{
${ }^{1}$ Professora Doutora do Curso de Geografia e do PPGPLAN na Universidade do Estado de Santa Catarina UDESC. E-mail: veraludias@gmail.com

${ }^{2}$ Geógrafa, Mestra em Planejamento Territorial e Desenvolvimento Socioambiental pelo PPGPLAN/UDESC

E-mail: mariacarol.soares@gmail.com

${ }^{3}$ Ver artigo A Construção Imobiliária em Florianópolis e as Leis de Regulamentação: Os Planos Diretores: uma colcha de retalhos desintegrada e desintegradora de autoria de Vera L. N. Dias, Júlio Ettore do Nascimento, Gustavo Moresco e Cristina Maria Dalla Nora. Publicado no livro Cadernos do Observatório Geográfico da Grande Florianópolis do PET Geografia UDESC, Volume 2, Editora Insular, Florianópolis, 2013, Págs. 181-214.
} 


\section{AGONÍA EN EL BARRIO ITACORUBI / FLORIANÓPOLIS / SC: CRÓNICAS DE UNA MUERTE ANUNCIADA}

Resumen: Este estudio busca conocer las particularidades de las alteraciones de zonificación en el barrio Itacorubi, ya que fue el barrio del Distrito Sede que más sufrió alteraciones en la zonificación desde la aprobación de la Ley 001/1997 hasta 2010. Uno de los objetivos de esta investigación es demostrar que las alteraciones de las propuestas en el Plan Director aisladamente, aunque legales, pueden influir y perjudicar la totalidad del Plan. Otro objetivo busca demostrar las consecuencias de las acciones políticas en el trazado urbano de la ciudad, que privilegia algunos pocos en detrimento de usos públicos y de mayor interés de la sociedad local. La metodología adoptada combinó técnicas de investigación en archivos - en especial los archivos del ayuntamiento de Florianópolis y levantamiento de campo en el barrio, además de análisis del mapeamiento de las alteraciones y; revisión bibliográfica sobre los Planes Directores, políticas públicas, planificación urbana y legislación urbana.

Palabras clave: Zonificación; Modificación de la Ley del Plan Director; Barrio Itacorubi; Florianópolis - SC

\section{INTRODUÇÃO}

A presente pesquisa procurou contribuir com o levantamento de dados básicos objetivando, em médio prazo, subsídios a propostas e formulação de políticas públicas para Florianópolis/SC. Tal município, que nos anos 2000, apresentou índices que o elegeram como uma das melhores capitais para se viver no país, enfrenta crescimento urbano considerável e a construção civil tem se mostrado uma rentável atividade econômica da cidade.

A voracidade imobiliária na Ilha tem produzido danos ao meio ambiente, sobretudo em se tratando de um ecossistema frágil e complexo como é o insular. Promover reflexão sobre as políticas públicas que envolvem o planejamento e gerenciamento urbanos é, desta forma, imprescindível para coibir abusos que infrinjam as leis (locais e federais) e danifiquem de forma definitiva parcelas consideráveis deste ecossistema urbano.

Segundo a publicação "Política Habitacional de Florianópolis", da gestão 2000/2004 da prefeitura municipal, "a Política Habitacional vem sendo concebida como um fator determinante da redução das desigualdades sociais em Florianópolis, aliada à reconquista gradativa da qualidade ambiental para todos os seus habitantes e visitantes" (p. 09). O Secretário de Obras da Gestão, Francisco de Assis, candidato à prefeitura ao fim do período, foi mais longe quando considerou: "A partir da atual gestão, começam a ser viabilizadas as 
condições para o tratamento desta problemática (política habitacional) de forma mais abrangente e sistematizada" (p. 11).

O documento também trouxe, em tabela, que o crescimento da população da cidade foi de 138.337 habitantes em 1970 para 341.781 em 2000, com uma taxa de urbanização de 97,04 (p. 32). Diz ainda que "Florianópolis dispõe de uma legislação urbana bastante ampla, mas... carecendo de um conjunto de instrumentos legais que... ofereça as bases legais para o seu enfrentamento" (p. 39) e culpa os limites marinhos e as áreas de preservação como responsáveis pelo aumento do custo de imóveis e redução de acesso a terra. Entretanto, muitos exemplos citados acima mostram a atuação da iniciativa privada como influência determinante sobre os custos. Então, pergunta-se: o discurso oficial foi posto em prática? Conseguiu a iniciativa privada "alargar" as leis em seu benefício, deixando as populações carentes limitadas pelo mar e pelas Áreas de Preservação Permanentes (APP's)? Somente detalhada pesquisa documental pode demonstrar tais suposições. Outro elemento sugerido pelo documento da prefeitura informava que:

Na prática, tem ocorrido a transformação de parcelas de Áreas de Exploração Rural AER - em ARP-0 (Áreas Residenciais Predominantes Zero, que indicam áreas de favelas e outras definidas para abrigar loteamentos populares) para a execução de conjuntos habitacionais, mas que, segundo os empreendedores, ao serem atendidos os parâmetros desta lei, inviabilizam o atendimento das camadas sociais mais necessitadas (p. 40).

Como este atendimento efetivamente foi inviabilizado? “...os projetos de alteração... têm sido aprovados sem muitas dificuldades, mas a ausência de dispositivos que explicitem critérios básicos de inserção urbana... comprometem sua função e adequação urbana" (p. 40/41). Por que faltaram tais dispositivos? Quais são? Essas foram algumas das perguntas de partida que deram origem a esta investigação.

O título - uma homenagem ao escritor colombiano - Gabriel García Márquez, anuncia os problemas que virão com o aumento populacional no Bairro Itacorubi, cuja população se desloca, em grande parcela, com transporte privado individual. Os desdobramentos de tais impactos urbanos podem ser sentidos na qualidade de vida dos moradores, e, também, para aqueles que o utilizam como lugar de passagem diária (deslocamentos entre o centro da cidade e os bairros da Lagoa da Conceição, Barra da Lagoa, Rio Vermelho, cujo acesso se faz 
exclusivamente pelo bairro Itacorubi e/ou entre a Trindade e o Norte da Ilha, cujo acesso é secundário).

Conhecer a extensão das alterações de zoneamento no bairro e os terrenos afetados por estas alterações foi o desafio desta pesquisa, que objetivou também conhecer os autores das leis de alteração do zoneamento, bem como os respectivos partidos políticos dos vereadores proponentes de tais leis. E, ainda, refletir sobre o Plano Diretor e suas implicações no bairro.

Essas informações não foram encontradas nos sites institucionais da Prefeitura Municipal de Florianópolis e do Instituto de Planejamento Urbano de Florianópolis (IPUF). Para conhecer os lugares afetados pelas alterações no zoneamento urbano (num total de 16 alterações ${ }^{4}$ ) do bairro foi preciso ampla pesquisa nos arquivos do IPUF cotejando os mapas e croquis constantes nas leis e construindo uma cartografia destas alterações ${ }^{5}$.

A pesquisa foi iniciada com o levantamento de informações sobre a área de estudo, em especial nos arquivos da Câmara Municipal de Vereadores, nos arquivos da Secretaria de Urbanismo e Serviços Públicos de Florianópolis (SUSP) e nos arquivos do Instituto de Planejamento Urbano de Florianópolis (IPUF). Posteriormente foram realizadas conversas com técnicos na prefeitura, alguns dos vereadores autores dos pedidos de alteração de zoneamento e representantes das instituições públicas que gerenciam e fiscalizam as obras na cidade.

Paralela a estas atividades foi realizada revisão bibliográfica dos estudos publicados sobre o tema, legislação vigente, os planos diretores e os mapas de zoneamento; identificando in loco a existência de obras construídas nos locais-alvo das alterações de zoneamento. Nos campos realizou-se um inventário dos prédios construídos e em construção desde os anos 1983 até 2015, com o fim de demonstrar o forte adensamento favorecido pelas alterações analisadas $^{6}$. A pesquisa é definida como "Estudo de Caso", pois tratou da descrição de

\footnotetext{
${ }^{4}$ Todas as leis alteradas foram Leis Complementares, a saber: 039/1999, 148/2004, 181/2005 (duas áreas alteradas, 246/2006, 247/2006, 265/2007, 287/2007, 314/2008, 047/2002 (5 áreas alteradas), 069/2004 e, 076/2004.

5 Além de não se conseguir estas informações de maneira fácil (nos órgãos oficiais), os resultados do mapeamento realizado são, por esta razão, aproximações possíveis tendo em vista a enorme dificuldade de conseguir localizar as alterações no traçado urbano a partir de croquis, feitos manualmente, sem precisão cartográfica e sem dados georreferenciados.

${ }^{6}$ Os dados obtidos aqui são aproximações, pois em muitos casos durante a pesquisa de campo as pessoas responsáveis pelos prédios e/ou obras se recusavam a dar informações e/ou não sabiam os dados para informar. Assim, fizemos aproximações tendo em vista o que era visível de fora dos prédios e tomando o cuidado para nunca exceder os dados. Desta decisão decorre o cuidado para que o número de prédios e de apartamentos seja pelo mínimo essa apontada, podendo ser mais, nunca menos.
} 
fatos/acontecimentos num recorte temporal e geográfico determinado: de 1983 à 2015, no bairro Itacorubi, município de Florianópolis.

\section{Histórico do Lugar e problematização ${ }^{7}$}

Florianópolis esteve no foco de diversos estudos e reportagens na década de 90 e início dos anos $2000^{8}$. Os dados divulgados bem como a publicidade em torno da qualidade de vida podem ter influenciado no aumento populacional da capital catarinense, que recebeu 29.000 novos habitantes somente entre os anos de 1991 e 1996. Nos anos 1998 Florianópolis foi eleita como a primeira capital e a segunda cidade brasileira com melhor classificação pelo Índice de Desenvolvimento Humano (IDH) ${ }^{9}$.

Entretanto, ainda que a mídia tenha elegido Florianópolis como a "meca da classe média"10, os dados sobre urbanização preocupam e ameaçam a estabilidade da cidade. A falta de moradias iniciada nos anos 80, época de grande crescimento da cidade e começo das ocupações irregulares ${ }^{11}$ nos morros do centro, nas margens da Via Expressa, bem como em extensas áreas nos balneários da Ilha foi largamente acentuada.

Marcon (1986) apud Binotto (1994:52) afirma que entre os anos 70 e 80, Florianópolis recebeu, basicamente, três correntes migratórias compostas por: a) Pessoas que vinham preencher cargos públicos na administração estadual e municipal ou em instituições como a Eletrosul ou a Universidade Federal de Santa Catarina; b) Estudantes universitários vindos do

\footnotetext{
${ }^{7}$ Esse item é uma versão resumida já apresentada no artigo mencionado na nota de rodapé $\mathrm{n}^{\circ} 3$.

8 Ver a este respeito as reportagens da revista VEJA de 22/10/1997, de 25/11/1998, de 07/04/1999, de 09/06/1999, de 28/07/1999 e de 07/03/1999; da revista ISTO É de 16/09/1998 e dados de uma pesquisa realizada em parceria pelo Programa das Nações Unidas para o Desenvolvimento (PNUD), pelo IPEA (Instituto de Pesquisa Econômica Aplicada) e pela Fundação João Pinheiro de Minas Gerais, divulgados em agosto de 2003, onde afirmam que Florianópolis foi a cidade brasileira que mais enriqueceu nas três últimas décadas (seu PIB per capita cresceu, em média, 6\% ao ano) e que a Grande Florianópolis (Florianópolis, São José, Biguaçu e Palhoça) têm o melhor Índice de Desenvolvimento Humano Municipal (IDH-M) do país $(0,86)$.

${ }^{9}$ Ver relatório do Programa das Nações Unidas para Desenvolvimento (PNDU). A ONU criou o IDH em 1990. Para tanto, utilizou basicamente três variáveis: a expectativa de vida ao nascer; escolaridade e Produto Interno Bruto (PIB). Essas três variáveis são expressas numa escala de zero a um e indicam o grau de desenvolvimento de um país. Quanto mais próximo do zero, pior é o desenvolvimento humano do país e, quanto mais próximo do um, melhor o IDH.

${ }^{10}$ Reportagem da revista Veja de 07/03/2001 cujo título era «Floripa Campeã: pintada de verde no mapa e recordista em estatísticas positivas, a capital catarinense é a meca da classe média».

${ }^{11}$ Entende-se por ocupação irregular aquela que não segue as normas legais - seja da propriedade da terra ou das leis urbanísticas do município. Mas a construção «irregular», em Florianópolis, não é exclusividade das camadas desfavorecidas, sendo um artifício das camadas médias e altas também. Segundo levantamento da Prefeitura Municipal de Florianópolis, realizado em 1994, cerca de 58\% dos domicílios foram construídos irregularmente na capital catarinense. (Miranda, 2001:65)
} 
interior ou de outros estados para frequentarem a UFSC e UDESC; e c) A migração ruralurbana ou urbana-urbana.

Este contingente se distribuiu de maneira desigual na cidade: a classe média-alta e alta ocupou os prédios de luxo da Avenida Beira-Mar Norte ou os condomínios do Distrito Sede, do Norte da Ilha ou na Lagoa da Conceição; b) a classe média se instalou na zona central da cidade $^{12}$, nas adjacências da UFSC e da Eletrosul e/ou nos demais balneários da Ilha, nem sempre de forma regular ${ }^{13}$ e; c) a população de baixa renda que se localizou nos morros, nas áreas planas e periféricas da Ilha, nas antigas zonas rurais, no Continente e nos municípios de São José, Palhoça e Biguaçu (Binotto, 1994:53)

Grande parte da população empobrecida que chegava à capital provinha da zona rural do Estado de Santa Catarina, que passava por um processo de concentração de terras, privilegiando culturas de exportação. Ao chegarem à capital, estes migrantes seguiram um trajeto muito conhecido: ergueram pequenas casinhas em terrenos que hoje são de preservação permanente (nas encostas dos morros) ou em áreas mais afastadas do centro da cidade e, depois, lançaram-se à procura de trabalho - geralmente informal e braçal - como construção civil, trabalho doméstico e serviços pontuais de curta duração.

Tal contingente populacional passou a utilizar terrenos nas encostas para construir “casebres... sem qualquer preocupação com o alicerciamento correto" (Castro, 1992:11), sem o olhar do poder público, como nos é exemplificado na extinção do Banco Nacional de Habitação durante o governo Sarney, envolto em escândalos e tendo cumprido apenas cerca de 10\% da sua meta de casas (Castro, 1992:09).

Em 1992, o IPUF contava 54 mil moradores de favelas em Florianópolis (Castro, 1992:08), e para tentar resolver tal questão a transferência de uma favela a outra localidade era efetuada. Entretanto, muitas vezes o que se buscava era o afastamento da classe baixa das zonas nobres para evitar a desvalorização dos que ali se localizavam, não levando em conta as necessidades dos moradores, como proximidade de áreas comerciais e/ou escolas.

\footnotetext{
12 Segundo Neumann, nos anos 80, acentua-se a queda na construção de número de edificações de 1 e 2 pavimentos, inicia-se a queda do número de construções com 3 e 4 pavimentos, e se eleva o aumento de construção de edificações com mais de 4 pavimentos, foram construídos no período 161 edificações. (1998: 75)

${ }^{13}$ Exemplo de ocupação irregular da classe média é o balneário do Campeche (no Sul da Ilha) ou Ingleses (no Norte) onde prevalece, pela legislação em vigor (Lei 2193/1985), terras para uso exclusivo rural onde é proibido, portanto, construir residências urbanas. Essa legislação não é cumprida nem fiscalizada, o que tem permitido um crescimento enorme destes dois bairros entre os anos 1990 e 2015.
} 
O movimento de migração para os municípios que compõem a região conurbada de Florianópolis foi muito importante a partir dos anos 70 e chegou a representar, no ano de 1996, quase metade da população total dos municípios, como pode ser observado na tabela 1:

Tabela 1: População Total e Não Natural dos Municípios da Aglomeração de Florianópolis

\begin{tabular}{|l|c|c|c|c|c|c|}
\hline Município & $\begin{array}{l}\text { Pop. } \\
\text { Total }\end{array}$ & $\begin{array}{c}\mathrm{N}^{\circ} \text { de migrantes } \\
\text { por município e \% }\end{array}$ & $\begin{array}{l}\text { Pop. } \\
\text { Total }\end{array}$ & $\begin{array}{c}\mathrm{N}^{\circ} \text { de migrantes } \\
\text { por município e \% }\end{array}$ & $\begin{array}{l}\text { Pop } \\
\text { Total }\end{array}$ & $\begin{array}{l}\mathrm{N}^{\circ} \text { de migrantes } \\
\text { por município e \% }\end{array}$ \\
\hline Biguaçu & 21.434 & $5.868(27,37 \%)$ & 34.063 & $11.133(32,68 \%)$ & 40.047 & $15.188(37,92 \%)$ \\
\hline Florianópolis & 187.871 & $68.436(36,42 \%)$ & 255.390 & $99.432(36,19 \%)$ & 271.281 & $128.473(47,35 \%)$ \\
\hline Palhoça & 38.031 & $5.866(15,42 \%)$ & 68.430 & $30.352(44,35 \%)$ & 81.176 & $38.264(47,13 \%)$ \\
\hline São José & 87.817 & $49.379(56,22 \%)$ & 139.493 & $77.255(55,38 \%)$ & 151.024 & $92.345(61,14 \%)$ \\
\hline Total & 335.153 & $129.549(38,65 \%)$ & 497.376 & $218.172(43,86 \%)$ & 543.528 & $274.270(50,46 \%)$ \\
\hline
\end{tabular}
Fonte: $\mathrm{IBGE}^{14}$.

Em Florianópolis, a chegada destes contingentes de novos moradores promoveu a valorização dos terrenos e das moradias nas áreas centrais da cidade, resultado do efeito oferta/procura. O Distrito Sede - formado pela parte continental e pela área centro-ocidental da Ilha (limitada dos demais bairros pelo Morro da Cruz e o da Queimada, além do Saco dos Limões) - foi o que mais cresceu num primeiro momento, seguido da expansão dos bairros que fazem divisa com o Distrito Sede. Por fim, o crescimento deu-se em direção dos balneários.

As classes média e alta escolheram o centro da cidade como lugar de moradia, conforme constatou Fernandez (1999:32), quando analisou dados de migração fornecidos pelo IBGE entre 1991 e 1996, ratificando, também, suspeita de migração interna no sentido bairros-centro: a região central apresenta as maiores taxas de absorção entre todos os bairros da cidade, confirmando a preferência desta zona como local para se morar. (Fernandez, 1999:134) Este fato fez com que aumentasse muito o preço dos terrenos e dos aluguéis, tirando dos migrantes do campo qualquer possibilidade de moradia nesses locais, pelo menos dentro do mercado formal.

Neumann (1998) fez uma pesquisa nos imóveis cadastrados em Florianópolis no período de 1982 a 1997 e comparou-a com a densidade demográfica (hab./km²) e com a taxa

\footnotetext{
${ }^{14}$ Os dados não foram atualizados, pois o IBGE mudou a forma de pesquisar estas informações dificultando a projeção dos dados desta tabela.
} 
de crescimento anual concluindo que o aumento de imóveis cadastrados cresceu três vezes mais que o aumento da população:

No final da década de 90, o número de imóveis cadastrados é cerca de $56 \%$ superior ao número de imóveis cadastrados no final da década de 80, e 147\% superior ao número dos imóveis registrados no início da década de 80, o que representa um aumento superior a 3 vezes o aumento da população para o mesmo período (Neumann, 1998: 71).

Além do aumento do número de imóveis, foi possível conhecer, também, algumas preferências de localização no centro da cidade através do cadastro de «licenças de habitese» ${ }^{15}$ da Prefeitura Municipal. Entre os anos de 1994 e 1999 as construções foram preferencialmente nas ruas do entorno do Shopping Center Beira-Mar, revelando o poder catalisador deste tipo de empreendimento para o mercado imobiliário das cercanias onde está instalado; informando, também, sobre a renda destes novos proprietários e o valor destas construções: localizações nobres tem relação direta com rendas elevadas. (Fernandez, 1999:42 e 63)

A opção das classes média e alta por morar no centro, perto dos serviços e facilidades urbanos, transformou o mercado de moradia em um negócio extremamente rentável para poucas construtoras que dominavam o mercado:

Conforme detectou Ilha (1998), cerca de seis a sete construtoras detém metade da participação da oferta de imóveis em todo município de Florianópolis, seja em valor total das unidades à venda, área total destas unidades ou mesmo número destas unidades que, indiferentemente, apresentam o mesmo comportamento na avaliação da participação acumulada do mercado. (Fernandez, 1999:44-45)

Isso sugere que a iniciativa privada deu preferência ao mercado mais rentável, seguro e solvável das camadas abastadas em detrimento das desfavorecidas que foram, então, abandonadas à própria sorte. Esta situação foi resumida por Binotto:

A incapacidade de prover habitações adequadas à maioria da população é uma incapacidade estrutural, devido à existência de uma grande massa de trabalhadores criada pelo capitalismo que, ao receber remunerações baixas ou instáveis, não se constitui em mercado real ou potencial para as empresas da promoção privada. Essas empresas se dedicarão ao atendimento

\footnotetext{
15 «Habite-se» é a designação popular de uma licença emitida pelas prefeituras que autoriza a ocupação dos imóveis novos ou reformados. A prefeitura é responsável pela fiscalização da construção e uma vez constatada a conformidade das normas exigidas em lei, a prefeitura emite essa licença.
} 
das camadas médias e altas que apresentam garantia de pagamento e, consequentemente, de lucros (Abreu, 1986) (Apud Binotto, 1994:38)

Os anos passaram e Florianópolis continua hoje com um acentuado perfil administrativo, comercial, residencial e turístico ${ }^{16}$ e os principais fluxos migratórios relacionam-se a estas esferas, o que justificou um incremento na construção civil, sobretudo em prédios públicos (Construção da nova sede do governo, o Centro Administrativo do Governo do Estado de SC, localizado na SC 401, inaugurado em outubro de 2003, o Tribunal de Justiça, em 2007, empreendimentos comerciais-imobiliários (Floripa Shopping Center em 2006, Shopping Iguatemi em 2007, Corporate Park em 2009, hotéis, centros comerciais, pousadas) e habitações (primeira e segunda residência - servindo como fonte de renda em período de veraneio ou como lazer).

A aprovação do Estatuto da Cidade em 2001 representou um avanço dos grupos da esquerda organizados do Brasil que, durante 13 anos, discutiram uma regulamentação federal para a política urbana. Segundo Rolnik (2001):

O Estatuto define uma concepção de intervenção no território que se afasta da ficção tecnocrática dos velhos Planos Diretores de Desenvolvimento Integrado, que tudo prometiam e nenhum instrumento possuíam para induzir a implementação do modelo idealizado proposto. De acordo com as diretrizes expressas no Estatuto, os Planos Diretores devem contar necessariamente com a participação da população e de associações representativas dos vários segmentos econômicos e sociais, não apenas durante o processo de elaboração e votação, mas, sobretudo, na implementação e gestão das decisões do Plano.

Em maio de 2005 o Ministério das Cidades lançou uma campanha nacional intitulada "Plano Diretor Participativo - Cidade de Todos" onde intentava a elaboração de Planos Diretores para municípios com população acima de 20 mil habitantes. Neste esforço, cerca de 1700 municípios brasileiros deveriam, até outubro de 2006, elaborarem ou reformularem seus planos diretores para normatizarem o crescimento urbano com base no Estatuto da Cidade Lei Federal 10.257 de 10 de julho de 2001 que regulamentou os artigos 182 e 183 da Constituição Federal, estabeleceu diretrizes gerais da política urbana e deu outras providências. O objetivo do Ministério das Cidades era regular o crescimento urbano, diminuindo os grandes e graves problemas socioambientais presentes nas grandes cidades.

O documento também considera obrigatória a revisão do Plano Diretor a cada dez anos, o que não aconteceu em Florianópolis. Em dezembro de 2014, no apagar das luzes do

\footnotetext{
${ }^{16}$ Há informações que destacam intensa atividade no ramo tecnológico na cidade nos últimos anos, em especial na área que alguns consideram Itacorubi Norte, mas não foi alvo deste estudo.
} 
governo do prefeito Cesar Souza Junior foi aprovado um Plano Diretor, Lei 482/2014, com muitas emendas, o que resultou em um longo processo de judicialização. Em 2015 o Tribunal Regional Federal da $4^{\text {a }}$ Região (TRF4), sentenciou a Prefeitura de Florianópolis a realizar audiências públicas e reuniões do Núcleo Gestor para o rebatimento do Plano aprovado em 2014, visando assim, maior participação popular. Com o cumprimento da sentença novas divergências ocorreram, culminando em uma ação no Superior Tribunal Federal, que em novembro de 2017 concedeu autonomia à PMF na condução do Projeto ${ }^{17}$.

Tendo em vista estas legislações, a pesquisa se formulou como contribuinte dos esforços necessários para conhecer, analisar e propor encaminhamentos viáveis à formulação de políticas públicas.

Para isso buscou-se conhecer as solicitações de alteração de zoneamento - instrumento legal - que foi utilizado por vereadores e prefeitos, que modificaram definições previstas no Plano Diretor. Identificar estas alterações no bairro Itacorubi auxilia a reflexão sobre o Planejamento Urbano e os interesses dos grupos sociais mais articulados e influentes da sociedade local.

\section{O Bairro Itacorubi e seu Crescimento}

Os primeiros passos em direção ao crescimento do bairro Itacorubi podem ser encontrados nos anos 1930, quando foi inaugurada a estrada - que em 1975 foi pavimentada e nomeada como SC-401 - Rodovia José Carlos Daux, que ligava o Itacorubi ao Norte da Ilha de Santa Catarina ${ }^{18}$. Nos anos 1940-1950 algumas poucas obras prenunciavam um caráter estudantil (que só iria se confirmar décadas depois com a presença de várias faculdades no local): a Escola Eleonor de Barros (1947) e a sede da APAE (1952 $\left.{ }^{19}\right)$.

17 Ver mais em: https://g1.globo.com/sc/santa-catarina/noticia/stj-acata-recurso-da-prefeitura-e-suspenderevisao-do-plano-diretor-de-florianopolis.ghtml

${ }^{18}$ Segundo a reportagem, a estrada começou a ser construída em 1922 e foi inaugurada em 1930, durante o governo de Adolfo Konder. Antes disso os moradores do Norte da Ilha chegavam ao centro de barco ou a cavalo. Ver Notícias do Dia de 30/03/2016, consultado em 10/09/2017: https://ndonline.com.br/florianopolis/noticias/construida-para-desenvolver-o-norte-da-ilha-sc-401-e-a-rodoviamais-perigosa-de-santa-catarina 19 Ver matéria no Jornal Hora de Santa Catarina de 02/09/2019, acessada em 09/09/2017: http://horadesantacatarina.clicrbs.com.br/sc/geral/noticia/2016/09/impasse-adia-construcao-de-nova-sede-daapae-em-florianopolis-7362813.html 
Costa (2011), entretanto, situa os anos 1960 como referência do crescimento e aponta a instalação, no bairro vizinho, da Universidade Federal de Santa Catarina (1960 e anos seguintes até a construção do campus ${ }^{20}$ ) e da Eletrosul (1978), como o estopim do processo.

A construção de prédios públicos e de rodovias teve importante papel na expansão do bairro na década de 1970: a construção da SC-404, rodovia Admar Gonzaga (antiga SC 93) iniciada em 1969 e inaugurada em 1972²1, a Epagri (1975); a pavimentação da rodovia SC401 (inaugurada em 1975²2), CCA-UFSC (1975-1977), a TELESC (1976), o CREA-SC (1978), a UDESC (Campus do Itacorubi foi criado em 1979), a CIDASC (1982) e, a construção da CELESC (1988). Segue abaixo uma linha temporal dos eventos anteriormente mencionados.

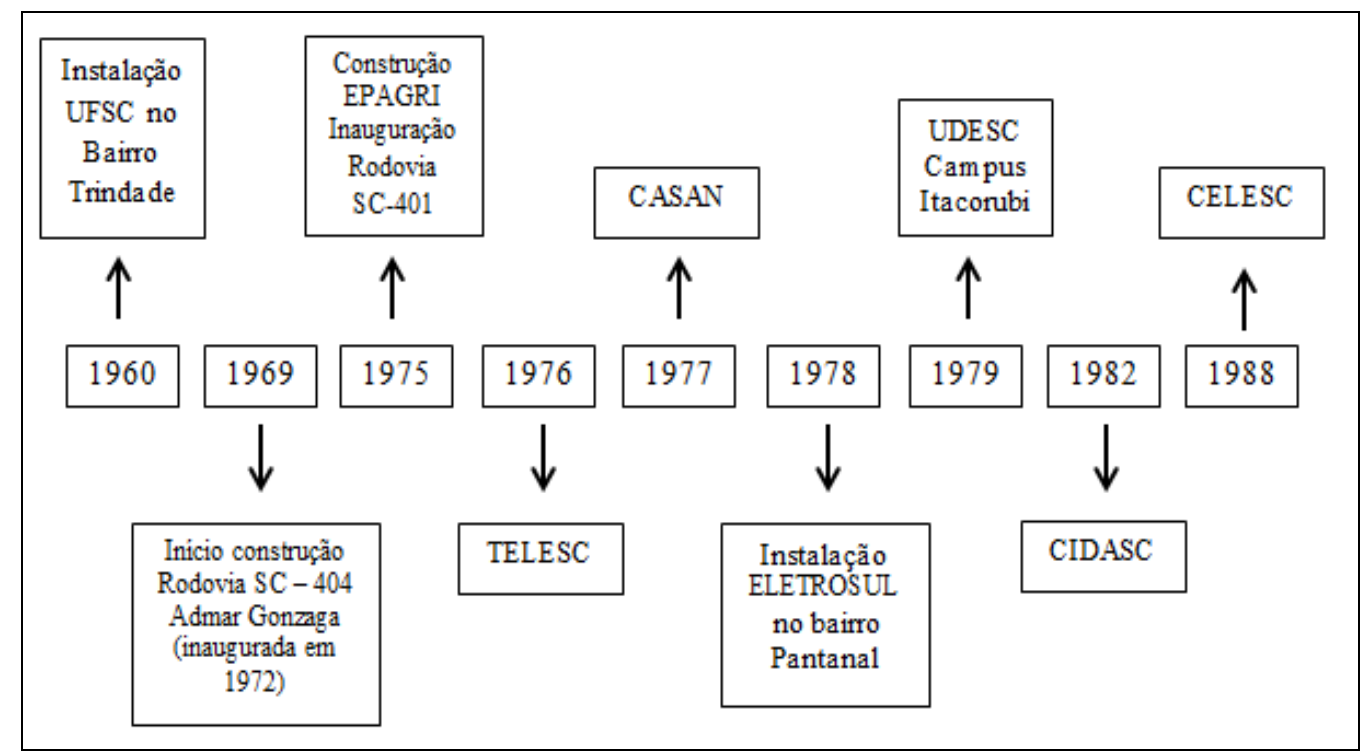

Fig. 1: Linha Temporal Alterações Urbanas. Fonte: as autoras (2017) com dados de Costa (2011).

A presença destas obras permite afirmar que as empresas públicas alavancaram o crescimento comercial e de serviços, concentrando empregos, que foram seguidos pelo aumento gradativo de residências unifamiliares térreas e de dois andares.

\footnotetext{
20 Ver a este respeito Livro UFSC 50 Anos, consultado em 10/09/2017: http://agecom.ufsc.br/files/2010/12/Livro_UFSC50Anos_2010_web.pdf

${ }^{21}$ Dado informado pela superintendência do Deinfra, Engenheiro Luiz Gonzaga.

${ }^{22}$ Ver entrevista com Colombo Sales, concedida a CBN Diário em 20/05/2016 e acessada em 10/09/2017: http://cbndiario.clicrbs.com.br/sc/noticia-aberta/documento-historico-ex-governador-colombo-machado-sallesfaz-90-anos-167010.html
} 
Segundo o censo do IBGE publicado em 1991, a população total do Itacorubi Norte e Itacorubi Sul, contava com 7.106 moradores. Em 2000 houve um aumento de 45\%, totalizando 10.307 e em 2010 um aumento de 52\%, perfazendo 15.665 moradores.

\section{População Total - Itacorubi Norte (Ano/Hab.)}

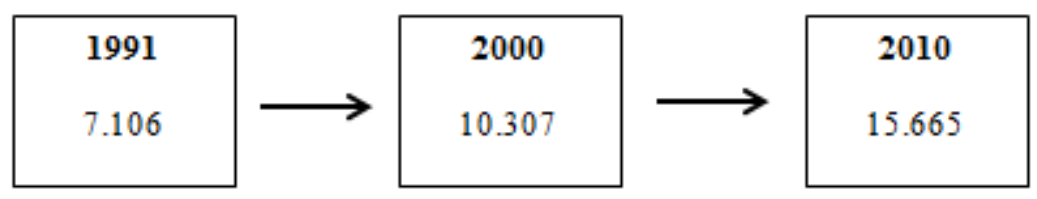

Fig. 2: População Total - Itacorubi Norte. Fonte: Fonte: as autoras (2017) com dados de Censo/IBGE.

Conforme pesquisa de campo $^{23}$, os primeiros edifícios residenciais no bairro datam de 1983 (Ilha do Arvoredo, com quatro blocos e Jardim Verde Vale, com um prédio). Agrupando os dados de dez em dez anos encontramos os seguintes resultados:

1) De 1983 até 1992 foram construídos 18 novos prédios de apartamentos, com altura entre quatro a cinco pavimentos e um total de 232 apartamentos. Neste mesmo período foram construídos 02 prédios comerciais (FIESC e SOCIESC), totalizando 20 novas edificações.

2) Entre os anos de 1993 e 2002 foram construídos 2.072 novos apartamentos no Itacorubi, distribuídos em 59 prédios exclusivamente residenciais. A maioria absoluta deles, $71 \%$, tinha altura até seis pavimentos e apenas $28,3 \%$ dos prédios tinha entre sete e dez pavimentos. Neste intervalo de tempo somente um prédio comercial de cinco andares foi construído, totalizando 60 novas edificações.

3) Na década entre 2003 e 2012 foram construídos 11 prédios comerciais e de serviços, 02 prédios residenciais mistos (comércio embaixo) e 64 prédios residenciais exclusivos, totalizando 77 novas construções e 2.778 novos apartamentos. Destas edificações, 50\% tinham altura até 6 pavimentos, $35 \%$ entre 7 e 10 pavimentos e $15 \%$ entre 11 e 15 pavimentos. É neste período que vemos o bairro se verticalizar, pois a metade das novas construções se situa entre 7 e 15 pavimentos.

\footnotetext{
${ }^{23}$ A pesquisa de campo foi realizada nos anos de 2014 e 2015 e alguns dados obtidos foram arredondados, pois houve quatro edificações onde não foi possível saber ao certo o número de prédios nem quantidade de apartamentos. Nestes poucos casos e tendo por base o tamanho visível dos edifícios fizemos uma aproximação sempre a menor para não superestimar os dados, ou seja, pode haver mais prédios e apartamentos do que os arrolados aqui, nunca menos.
} 
4) Este fenômeno se repetiu entre os anos 2013 e 2015 quando findou a pesquisa de campo. Neste intervalo de apenas três anos, 926 novos apartamentos foram construídos em 14 novos edifícios residenciais. Destes, apenas dois eram de cinco pavimentos (14\%), quatro tinham altura entre 6 e 10 pavimentos (28\%) e oito entre 11 e 15 pavimentos, representando $57 \%$ dos prédios residenciais construídos. Acima de seis andares tivemos, portanto, $85 \%$ das construções edificadas no período. Dois prédios comerciais (um de cinco e outro de sete pavimentos) foram erguidos, totalizando 16 novas construções neste ínterim.

Na pesquisa de campo foram identificados, ainda, 19 prédios cujas datas de construção não foram possíveis de serem conhecidas. Estas edificações abrigavam 275 apartamentos.

Tabela 2: Imóveis de acordo com período

\begin{tabular}{|c|c|c|c|c|}
\hline Período & $\begin{array}{l}\mathrm{N}^{\circ} \text { de } \\
\text { Imóveis }\end{array}$ & Tipo de Imóveis & $\begin{array}{c}\text { Número } \\
\text { Apartamentos }\end{array}$ & Pavimentos \\
\hline $1983-1992$ & 20 & $\begin{array}{l}18 \text { residenciais } \\
2 \text { comercial }\end{array}$ & 232 & 04,05 e 06 pavimentos \\
\hline $1993-2002$ & 60 & $\begin{array}{l}59 \text { residenciais } \\
01 \text { comercial }\end{array}$ & 2.072 & $\begin{array}{c}71 \% \text { até } 06 \text { pavimentos } \\
28,3 \% \text { entre } 07 \text { e } 10 \text { pavimentos }\end{array}$ \\
\hline $2003-2012$ & 77 & $\begin{array}{l}64 \text { residenciais } \\
11 \text { comerciais e } \\
\text { de serviços } \\
02 \text { mistos }\end{array}$ & 2.778 & $\begin{array}{l}50 \% \text { até } 06 \text { pavimentos } \\
35 \% \text { entre } 07 \text { e } 10 \text { pavimentos } \\
15 \% \text { entre } 11 \text { e } 15 \text { pavimentos }\end{array}$ \\
\hline $2013-2015$ & 16 & $\begin{array}{l}14 \text { residenciais } \\
02 \text { comerciais }\end{array}$ & 926 & $\begin{array}{l}14 \% \text { de } 05 \text { pavimentos } \\
28 \% \text { entre } 06 \text { e } 10 \text { pavimentos } \\
57 \% \text { entre } 11 \text { e } 15 \text { pavimentos }\end{array}$ \\
\hline SUBTOTAL & 173 & 173 & 6.008 & - \\
\hline $\begin{array}{c}\text { Prédios não } \\
\text { datados }\end{array}$ & 19 & 19 & 275 & - \\
\hline TOTAL & 192 & 192 & 6.283 & - \\
\hline
\end{tabular}

Fonte: as autoras (2017).

Organizando os dados de outra maneira, a fim de identificar mais precisamente o momento em que iniciou a verticalização, foi possível constatar o intervalo entre os anos 2001 e 2010 como fundamentais. Um número expressivo de prédios (47\%) construídos neste período tinha seis e acima de seis pavimentos. Neste intervalo foram construídos 57 prédios e a altura deles aumentou. Até cinco pavimentos encontram-se $53 \%$ das edificações (25\% menos que na década anterior -1991 até 2000-, que foi de 78\%); entre seis e oito pavimentos 
$28 \%$ e, de nove a doze pavimentos, $19 \%$ dos novos prédios. Neste espaço de tempo foram construídos 1.774 apartamentos.

Os próximos cinco anos (2011 a 2015) bateram todos os recordes: 43 novos prédios. Trinta e seis residenciais, um misto e seis comerciais. Esta distribuição já indica oferta de novos tipos de imóveis no bairro, os "comerciais e de serviços privados". Estas edificações buscam suprir novas necessidades que o aumento da densidade populacional provocou no Itacorubi.

Dos 43 edifícios, $18 \%$ tem altura entre quatro e cinco andares. Nenhum prédio de seis andares. De sete a doze pavimentos encontramos a maioria dos prédios do período $(65 \%)$ e aparece uma nova categoria de imóveis ainda mais altos: entre treze e quinze pavimentos, representando $16 \%$ das construções. Ou seja, acima de oito andares encontramos $67 \%$ das construções do período. O incremento na quantidade de apartamentos é o maior registrado nos últimos 40 anos: 2.246 novos apartamentos foram disponibilizados no mercado do bairro em apenas cinco anos.

Em relação às salas comerciais e de serviços privados os dados são muito incompletos, mas pelo menos 300 novas salas podem ser computadas neste período ${ }^{24}$.

No intervalo de 32 anos, entre 1983 e 2015, foram construídos 192 novos prédios, abrigando pelo menos 6.283 novos apartamentos. Nos últimos cinco anos, entretanto, se produziram $22 \%$ destes imóveis e $36 \%$ dos apartamentos. Estes dados são impressionantes, do ponto de vista do impacto destas construções para a mobilidade e adensamento, de um bairro que se pode considerar pequeno.

Em relação à mobilidade é importante lembrar que existem apenas duas grandes vias responsáveis pelo escoamento rodoviário do bairro: uma rodovia, a SC-404, e uma rua, a Pastor Willian Richard Schisler Filho, que cruzam longitudinalmente o bairro e que atendem, junto com pequenas transversais e paralelas, o deslocamento dos moradores de todos os prédios aqui levantados.

\footnotetext{
${ }^{24}$ Mais uma vez é importante lembrar que os dados obtidos no levantamento de campo foram, em muitos casos, imprecisos, em função dos depoentes não saberem e/ou não quiserem transmitir as informações. Nestes casos foi realizado cálculos de aproximação com as evidências encontradas (observação da construção, número de andares e metragem quadrada). Nesta aproximação foi mantido o cuidado para que os resultados não distorcessem a realidade aumentando as estimativas e, sim, aferissem o mínimo visível, que foi computado.
} 


\section{O crescimento e a legislação vigente ${ }^{25}$}

Além das duas formas de agrupamentos feitos acima, para fins de análise, reuniram-se os dados com o seguinte critério: antes e depois do Plano Diretor do Distrito Sede (Lei 001/1997), que regulamenta o bairro Itacorubi. Obtiveram-se os seguintes resultados.

1) Antes - Durante os quatorze anos que separam a construção dos primeiros prédios no Itacorubi (1983) e a aprovação do Plano Diretor do Distrito Sede (1997) foram construídos 58 prédios, abrigando 1.578 apartamentos. Do total de prédios construídos (58) 51\% tinham até quatro andares, $43 \%$ cinco andares e $6 \%$ oito andares.

2) Depois - Nos dezessete anos seguintes (de 1998 até 2015) foram construídos 13 prédios comerciais e públicos, 02 prédios mistos e 100 edifícios exclusivamente residenciais, com 4.430 apartamentos. Usando os mesmos critérios do período anterior, mas arredondando os dados já que foi construído quase o triplo de edifícios, até quatro pavimentos tem-se $23 \%$ dos prédios, cinco pavimentos $11 \%$, de seis a oito pavimentos $29 \%$ e, de nove a quinze andares $36 \%$.

Tabela 3: Dados - Antes e Depois do Plano Diretor de 1997.

\begin{tabular}{|c|c|c|c|c|}
\hline PERÍODO & N $^{\circ}$ IMÓVEIS & TIPO DE IMÓVEIS & N $^{\circ}$ APARTAMENTOS & \multicolumn{1}{c|}{ PAVIMENTOS } \\
\hline \multirow{2}{*}{ ANTES } & 58 & 58 residenciais & 1.578 & $\begin{array}{l}51 \% \text { até } 04 \text { pavimentos } \\
43 \% \text { de } 05 \text { pavimentos }\end{array}$ \\
\hline \multirow{2}{*}{ DEPOIS } & \multirow{2}{*}{115} & $\begin{array}{l}100 \text { residenciais } \\
13 \text { comerciais e } \\
\text { públicos } \\
02 \text { mistos }\end{array}$ & $\begin{array}{l}23 \% \text { até } 04 \text { pavimentos } \\
11 \% \text { de } 05 \text { pavimentos } \\
28 \% \text { de } 06 \quad \text { até } 08 \\
\text { pavimentos } \\
\text { de } 09 \text { até } 15\end{array}$ \\
\hline
\end{tabular}

Fonte: as autoras (2017).

Observando os resultados pode-se afirmar que a verticalização do bairro se intensificou sob a batuta do Plano Diretor do Distrito Sede de 1997. Este Plano foi bastante permissivo e estimulou gabaritos altos de construção, que adensaram rapidamente o bairro.

${ }^{25}$ Considerando vigente o Plano Diretor do Distrito Sede de 1997, pois a Lei 482/2014, do Plano Diretor de Florianópolis, ainda está em litígio no momento da escritura deste artigo. 
A Lei Municipal 5504, de 21/07/1999, foi quem, de fato, criou os bairros do Distrito Sede. Segundo esta Lei o bairro Itacorubi é a área compreendida entre:

O bairro Itacorubi corresponde as Unidades Espaciais de Planejamento - UEP'S 5, 11 e 19. A zona compreendida nos seguintes elementos físicos e eixos dos logradouros públicos: da foz do córrego entre a ponta do Lessa e o Manguezal do Itacorubi, segue contornando o Manguezal do Itacorubi até as proximidades da Escola Superior de Turismo e Hotelaria, em direção oeste-leste por uma linha seca, reta e imaginária do mar até as extremas dos lotes com inscrições imobiliárias 45.82.011.0373.001 (exclusive) e 45.82.011.0464.001 (inclusive) este último trata-se da Escola Superior de Turismo e Hotelaria, na rodovia SC-401 em direção ao norte da Ilha até encontrar a rua Mané Vicente, rua Mané Vicente até a rua Sem Denominação com o código de logradouro 313726; rua Sem Denominação onde encontramos a cota 94, daí subindo a linha de cumeada, passando pelas cotas 319 , $323,342,334$ e 354, continuando pela linha de cumeada até a cota 478, novamente pela linha de cumeada em direção oeste-leste, passando pela cota 423 , novamente pela linha de cumeada em direção norte-sul, passando pelas cotas 329, 332, 362, 263 e 328, no Morro do Assopra, da cota 328 até a curva de nível 260 na estrada do Sertão do Assopro (denominação não oficial), estrada do Sertão do Assopro em direção a rodovia Admar Gonzaga, cruzando esta rodovia até a extrema dos lotes com inscrições imobiliárias 53.39.072.0710.001 (exclusive) e 53.39.072.0399.001 casa no 4238 (inclusive); daí segue pela rua Sem Denominação (código de logradouro 318987) até seu término; segue subindo a linha de cumeada até a cota 212, segue agora descendo pela linha de cumeada passando pela cota 133 até cruzar a rua Vera Linhares de Andrade; daí por uma linha seca, reta e imaginária em direção oeste até encontrar o rio Itacorubi com a avenida Ângelo Crema, neste ponto do rio Itacorubi segue descendo o mesmo até encontrar a ponte na avenida Madre Benvenuta; da ponte, continuando descendo o rio Itacorubi, até a via projetada Principal Insular - PI -3 (conforme Lei Complementar 001/97), daí em direção oeste até a avenida Prof. Henrique Silva Fontes, avenida Prof. Henrique Silva Fontes até encontrar a avenida Governador Irineu Bornhausen; avenida Governador Irineu Bornhausen até encontrar o córrego entre o Manguezal do Itacorubi e a ponta do Lessa; e deste até sua foz (...).

Para Costa (2011:40), o Itacorubi é um "subcentro, um núcleo secundário" de grande relevância para a cidade, pois a posição do bairro é mais central em relação à Ilha do que o próprio centro da cidade. O autor destaca que a localização geográfica da Bacia Hidrográfica do Rio Itacorubi tem enorme importância para a rede viária da cidade, representando um verdadeiro "nó" do ponto de vista da mobilidade urbana, mas, também, do ponto de vista sócio-econômico, cujos interesses estariam explícitos no recente crescimento do bairro.

Estes elementos, aliados à pequena mobilidade urbana, com um dos piores sistemas de transporte coletivo urbano ${ }^{26}$, têm colocado desafios para o crescimento e manutenção da qualidade de vida na cidade, em especial no Itacorubi.

\footnotetext{
26 Ver matérias como: 1)Matéria do Diário Catarinense de 26/05/2009 consultada em 10/09/2017. http://dc.clicrbs.com.br/sc/noticias/noticia/2009/05/florianopolis-tem-pior-mobilidade-urbana-do-brasil2523317.html 2) Matéria do Notícias do Dia de 03/06/2012, acessada em 10/09/2017: https://ndonline.com.br/florianopolis/noticias/o-caotico-sistema-do-transporte-coletivo-em-florianopolis
} 
Em pesquisa concluída em 2012 constatou-se que os bairros de Florianópolis que mais sofreram alterações de zoneamento do Distrito Sede foram, respectivamente, o Itacorubi, com 16 alterações $^{27}$ e, Trindade, com 11 alterações. Essa investigação também esclareceu que parte significativa destas modificações foi mais permissiva, do ponto de vista da construção, ou menos restritiva, e que contribuiu para aquilo que pretendia "conter": o tal crescimento desordenado. Como visto na tabela que segue:

Tabela 4: Leis Complementares - Itacorubi

\begin{tabular}{|c|c|c|c|c|c|}
\hline Bairro & $N^{0}$ da Lei & $\begin{array}{c}\text { Área } \\
\text { Alterada }\end{array}$ & $\begin{array}{c}\text { Área } \\
\text { Implementada }\end{array}$ & $\begin{array}{c}\text { Avaliação quanto à } \\
\text { construção (mais } \\
\text { ou menos } \\
\text { restritiva) }\end{array}$ & $\begin{array}{c}\text { Encontrada no } \\
\text { Geoprocessamento } \\
\text { Corporativo - PMF }\end{array}$ \\
\hline \multirow{15}{*}{$\begin{array}{c}\mathbf{I} \\
\mathbf{T} \\
\mathbf{A} \\
\mathbf{C} \\
\mathbf{O} \\
\mathbf{R} \\
\mathbf{U} \\
\mathbf{B} \\
\mathbf{I}\end{array}$} & $\begin{array}{l}\text { 1) LEI COM. PMF } \\
038 / 1999\end{array}$ & $\begin{array}{l}\text { ARP-5, } \\
\text { ARE-6 }\end{array}$ & ACI & Mais & - \\
\hline & $\begin{array}{l}\text { 2) LEI COM. PMF } \\
148 / 2004\end{array}$ & $\begin{array}{l}\text { ARE-6, } \\
\text { APL }\end{array}$ & APP, ACI & Mais & - \\
\hline & $\begin{array}{l}\text { 3) LEI COM. PMF } \\
181 / 2005\end{array}$ & APL & $\begin{array}{l}\text { ARP-0, ACI, } \\
\text { AVL }\end{array}$ & Menos & \multirow[t]{2}{*}{ SIM } \\
\hline & $\begin{array}{l}\text { 4) LEI COM. PMF } \\
181 / 2005\end{array}$ & ARE-2 & AMS & Menos & \\
\hline & $\begin{array}{l}\text { 5) LEI COM. PMF } \\
\text { 246/2006 }\end{array}$ & APL & ARE-6 & Menos & SIM \\
\hline & $\begin{array}{l}\text { 6) LEI COM. PMF } \\
\text { 247/2006 }\end{array}$ & ARP-4 & ARP-5 & Menos & SIM \\
\hline & $\begin{array}{l}\text { 7) LEI COM. PMF } \\
\text { 265/2007 }\end{array}$ & $\begin{array}{l}\text { ARE-3, } \\
\text { APL }\end{array}$ & ARE-5 & Menos & $\begin{array}{c}\text { Área no Morro do } \\
\text { Quilombo, de difícil } \\
\text { delimitação }\end{array}$ \\
\hline & $\begin{array}{l}\text { 8) LEI COM. PMF } \\
\text { 287/2007 }\end{array}$ & ARE-2 & AVL & Mais & - \\
\hline & $\begin{array}{l}\text { 9) LEI COM. PMF } \\
\text { 314/2008 }\end{array}$ & $\begin{array}{l}\text { AVL, } \\
\text { AMC-3 }\end{array}$ & ASE-3 & Não altera & - \\
\hline & $\begin{array}{l}\text { 10) LEI COM. CMF } \\
047 / 2002\end{array}$ & - & AST-1 & $\begin{array}{c}\text { Não altera } \\
\text { (construção de via } \\
\text { pública) }\end{array}$ & - \\
\hline & $\begin{array}{l}\text { 11) LEI COM. CMF } \\
047 / 2002\end{array}$ & $\begin{array}{l}\text { ARE-3, } \\
\text { APL }\end{array}$ & ARE-4 & Menos & \multirow{4}{*}{$\begin{array}{l}\text { Encontrada área } \\
\text { grande esquerda } \\
\text { (sentido Lagoa- } \\
\text { Itacorubi). As duas } \\
\text { áreas menores da } \\
\text { direita não foram } \\
\text { identificadas }\end{array}$} \\
\hline & $\begin{array}{l}\text { 12) LEI COM. CMF } \\
047 / 2002\end{array}$ & APP & APL & Menos & \\
\hline & $\begin{array}{l}\text { 13) LEI COM. CMF } \\
047 / 2002\end{array}$ & ARP-5 & AVL & Mais & \\
\hline & $\begin{array}{l}\text { 14) LEI COM. CMF } \\
047 / 2002\end{array}$ & ARE-3 & ARP-2 & Menos & \\
\hline & 15) LEI COM. CMF & ACI & AMC-2, AVL & Não altera & - \\
\hline
\end{tabular}

3) Matéria no sítio Mobilize- Mobilidade Urbana Sustentável de 30/06/2014, acessada em 10/09/2017: http://www.mobilize.org.br/noticias/6596/pesquisa-aponta-florianopolis-com-a-pior-mobilidade-urbana-do-

brasil.html 4) Matéria no G1 de 21/03/2016, acessada em 10/09/2017: http://www.mobilize.org.br/noticias/6596/pesquisa-aponta-florianopolis-com-a-pior-mobilidade-urbana-do-

brasil.html 5) Matéria do Notícias do Dia de 27/07/2017, acessada em 10/09/2017: https://ndonline.com.br/florianopolis/coluna/fabio-gadotti/integracao-do-transporte-publico-da-grande-

florianopolis-nao-inclui-sistema-da-capital

${ }^{27}$ Descobriu-se depois que algumas alterações na área considerada Itacorubi não eram exatamente na área da pesquisa. A Lei Complementar 069/2004, por exemplo, situa-se no bairro Santa Mônica e não no Itacorubi, apesar de pegar grande parte da Avenida Madre Benvenuta. Essa Lei foi descartada deste estudo. 


\begin{tabular}{|c|c|c|c|c|c|}
\hline Bairro & $\mathbf{N}^{0}$ da Lei & $\begin{array}{c}\text { Área } \\
\text { Alterada }\end{array}$ & $\begin{array}{c}\text { Área } \\
\text { Implementada }\end{array}$ & $\begin{array}{c}\text { Avaliação quanto à } \\
\text { construção (mais } \\
\text { ou menos } \\
\text { restritiva) }\end{array}$ & $\begin{array}{c}\text { Encontrada no } \\
\text { Geoprocessamento } \\
\text { Corporativo - PMF }\end{array}$ \\
\hline & $076 / 2004$ & & & & \\
\hline
\end{tabular}

Fonte: as autoras (2017) com base na pesquisa em arquivos da Câmara Municipal de Florianópolis, pesquisa in loco e análise das tabelas e índices de construção do Plano Diretor 001/1997.

O quadro expõe que, das quinze leis alteradas, a maioria (8) é menos restritiva, quatro são mais restritivas e três delas permanecem com graus de restrição semelhantes.

Ao que parece, nas narrativas feitas nas entrevistas com dois vereadores e técnicos da prefeitura, as razões para as interferências dos prefeitos e vereadores demandantes das alterações giravam em torno de um discurso técnico de "modernização" da cidade e, também, para atender demandas da população. Além disso, de maneira geral os Planos Diretores não evocavam o conjunto da cidade, sempre vista de maneira parcial: o Plano para os Balneários (1985) era um e para o Distrito Sede (1997) era outro. Essa visão fragmentada da cidade e as contínuas mudanças no Plano Diretor permitiu que grupos mais organizados obtivessem êxito nas suas demandas que se tratavam, em sua maioria, de interesses privados.

Segundo a Lei Complementar PMF 001/1997, que instituiu o Plano Diretor do Distrito Sede, o zoneamento do Itacorubi tinha extensões expressivas designadas para Área de Preservação Permanente (APP) e Área de Preservação Limitada (APL), mas tinha também áreas muito grandes destinadas a Residências Exclusivas (ARE 1.044 651,861m²) e Residências Predominantes (ARP - 768 387,959). Observe a tabela abaixo ${ }^{28}$ :

\footnotetext{
${ }^{28}$ Área Comunitária Institucional (ACI), Área Mista Central (AMC), Área de Preservação Limitada (APL), Área de Preservação Permanente (APP), Área para Parque Tecnológico (APT), Área Residencial Exclusiva (ARE), Área Residencial Predominante (ARP), Área do Sistema de Saneamento e Energia (ASE) e Área Verde de Lazer (AVL).
} 
Tabela 5: Áreas - Tipo de Zoneamento da área estudada

\begin{tabular}{|c|c|}
\hline Tipo de Zoneamento & $\mathbf{M}^{2}$ \\
\hline ACI & $826.357,094$ \\
\hline AMC*-3 & $65.617,683$ \\
\hline AMC*-4 & $1.290 .36,857$ \\
\hline AMC-2 & $2.540,351$ \\
\hline AMC-3 & $17.826,522$ \\
\hline AMS & $59.408,094$ \\
\hline APL & $1.604 .850,795$ \\
\hline APP & $2.076 .387,159$ \\
\hline APT-3 & $68.000,577$ \\
\hline ARE-3 & $234.796,633$ \\
\hline ARE-4 & $129.742,677$ \\
\hline ARE-5 & $353.241,405$ \\
\hline ARE-6 & $326.871,146$ \\
\hline ARP*-5 & $483.562,891$ \\
\hline ARP-0 & $37.130,139$ \\
\hline ARP-1 & $56.440,759$ \\
\hline ARP-2 & $95.826,843$ \\
\hline ARP-4 & $93.570,609$ \\
\hline ARP-5 & $1.856,718$ \\
\hline ASE-3 & $39.824,324$ \\
\hline AVL & $23.280,904$ \\
\hline Total Geral & $\mathbf{6 . 7 2 6 . 1 7 0 , 1 8}$ \\
\hline
\end{tabular}

Fonte: as autoras (2017) com base em arquivo do Plano Diretor cedido pelo IPUF e recorte de imagem realizado no software ArcGis/Esri.

Este zoneamento era complementado por texto explicativo, baseado na tríade CDP (Condicionantes, Deficiências e Potencialidades). Neste documento se reconhecia que o bairro possuía áreas com ocupação desordenada ou dispersa (pág. 23), com deficiências de infraestrutura urbana (pág. 30), em especial áreas com falta de transporte público no Itacorubi Sul (pág. 27), áreas com deficiência de infraestrutura social - escolas (pág. 28), com deficiência de serviços e comércio vicinal (pág. 29), com usos conflitantes com o entorno - o caso do aterro sanitário da Comcap no mangue do Itacorubi (págs. 21 e 22); mas, mesmo assim, designava parcelas importantes para expansão de moradias (ver Plano Diretor pág. 30); ainda que estas áreas fossem menores do que aquelas destinadas à preservação. Este incentivo, na verdade, era tributário de outras considerações também presentes no documento do Plano, das "potencialidades" do bairro. Duas potencialidades se destacavam: 1) como 
“área própria para proteção ambiental/paisagística" (pág. 32) - as áreas de mangue, em especial, o mangue do Itacorubi para realização da piscicultura (pág. 35) e; 2) como área para uso comunitário/institucional, "para expansão de usos administrativos, formando um eixo de administração, através da ocupação de terrenos até o aterro sanitário (Norte) e até o Besc (Sul)" (pág. 39).

A área escolhida como piloto (Imagem 1) nesta pesquisa difere um pouco da área legal do bairro. O campo foi delimitado pelo adensamento populacional, em especial aquele resultante da verticalização das moradias e dos prédios públicos e de serviços privados: área limítrofe ao Sul com a Rodovia Admar Gonzaga (SC404) e suas adjacências, que serve de acesso ao bairro da Lagoa da Conceição, e a Oeste com a Rodovia José Carlos Daux (SC 401), que permite o acesso ao Norte da Ilha. Das áreas lindeiras a estas duas rodovias em direção ao Norte, ao cume do Morro do Assopra que divisa o bairro.

Localizando as áreas alteradas no mapa (Imagem 1) e calculando aproximadamente sua extensão ${ }^{29}$, se percebe que cerca de 500 mil metros quadrados obtiveram gabaritos e restrições menos limitantes do que aquelas previstas no Plano de 1997, como pode ser verificado na tabela abaixo:

Tabela 6: Áreas dos polígonos das Leis Complementares

\begin{tabular}{|c|c|c|c|c|c|c|}
\hline Lei & $\mathbf{0 4 7 / 2 0 0 2}^{\mathbf{3 0}}$ & $\mathbf{1 8 1 / 2 0 0 5}$ & $\mathbf{2 4 6 / 2 0 0 6}$ & $\mathbf{2 4 7 / 2 0 0 6}$ & $\mathbf{2 6 5 / 2 0 0 7}$ & TOTAL \\
\hline Área & 148.053 & 11.576 & 22.375 & 12.735 & 280.499 & 475.238 \\
\hline
\end{tabular}

Fonte: as autoras (2017) com dados do Google Earth.

\footnotetext{
${ }^{29}$ Este cálculo é aproximado, na medida em que não foi possível, a partir dos croquis e dos desenhos feitos a mão, encontrados junto às leis de alteração de zoneamento, se obter qualidade de localização e pontos georreferenciados que permitam cálculos mais precisos.

${ }^{30}$ Nesta Lei não foram calculadas duas áreas menores - uma alterada para AVL e outra em ARP2 - por não ter sido possível localizá-las no mapa.
} 


\section{LOCALIZAÇÃO DA ÁREA DE ESTUDO}
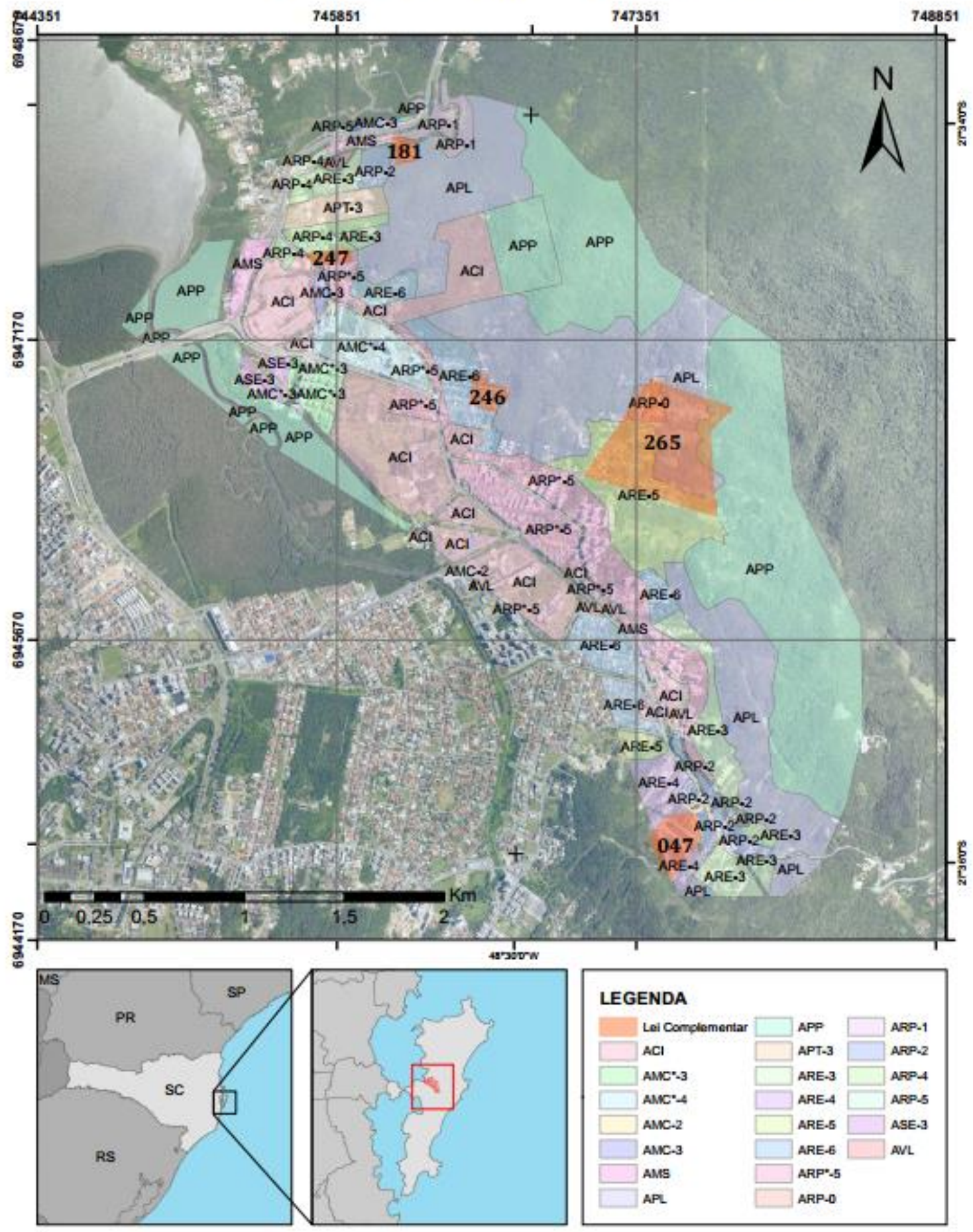

Produto cartográfico elaborado com recursos do Laboratório de Geoprocessamento da UDESC - GeoLab e CNPq. Informaçōes técnicas: DATUM SIRGAS 2000 FUSO 225 RASTER: Secretaria de Desenvolvimento Sustentável - SDS/SC VETOR: Limites Politicos - IBGE / Plano Diretor - P.M.F.

Produçaà: João Daniel Barbosa Martins Maria Carolina Soares

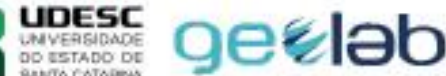

Imagem 1: Localização da área de estudo. 
Estes dados, aliados às informações obtidas na pesquisa de campo do forte adensamento nos últimos dez anos no bairro (autorizados pela Lei 001/1997), sugerem patamares bastante preocupantes de adensamento e mobilidade precária; corroborando com as premonições de caos urbano e diminuição da qualidade de vida dos moradores do bairro.

As alterações feitas a varejo e de forma continuada no zoneamento dos Planos Diretores contribuem para que o acesso à ocupação do solo ocorra de maneira diferenciada, privilegiando grupos mais organizados e melhor representados no poder executivo municipal. E, também, para que as instituições públicas de planejamento e gestão sejam desacreditadas, ao estilo da máxima sugerida por Flávio Villaça “de que há leis que pegam e outras que não pegam no Brasil”.

\section{Políticos, Partidos e Leis de Alteração do Zoneamento}

Essa pesquisa buscou, ainda, identificar os políticos propositores das leis de alteração do zoneamento e a quais partidos pertenciam na época das solicitações. As dificuldades para analisar a participação dos políticos e seus partidos foram de diversas ordens. Com muita frequência políticos trocam de partidos e, por esta razão, a atribuição das alterações para partidos específicos possui especificidades. Ainda assim, o exercício das somatórias foi realizado e com o resultado pode-se constatar que a maioria absoluta das proposições de alteração de lei partiu de vereadores ligados à partidos considerados de direita.

Para a referida consideração utilizou-se a conceituação de CARREIRÃO (2006:143) para quem os partidos políticos no Brasil seguem a seguinte classificação no eixo direitaesquerda: Direita: PP (PPB; PPR; PDS) ; PFL; PRN; PDC; PL; PTB; PSC; PSP; PRP; PSL; PSD e PRONA; Centro: PMDB e PSDB; Esquerda: PT; PDT; PPS; PCdoB; PSB; PV; PSTU; PCO e PMN. Os projetos de alteração bem como os vereadores/partidos estão apresentados na tabela 7 . 
Tabela 7: Leis Complementares e Partidos Políticos - Itacorubi

\begin{tabular}{|c|c|c|c|}
\hline $\mathrm{N}^{\mathrm{o}}$ da Lei & $\begin{array}{c}\text { Políticos que assinaram } \\
\text { Lei }\end{array}$ & $\begin{array}{l}\text { Partido } \\
\text { Político }\end{array}$ & $\begin{array}{l}\text { Lei mais ou menos } \\
\text { restritiva }\end{array}$ \\
\hline $\begin{array}{l}\text { 1) LEI COM. PMF } \\
038 / 1999\end{array}$ & $\begin{array}{c}\text { D. J. Machado } \\
\text { João Bittencourt } \\
\text { Michel Curi } \\
\text { Paula Ávila da Silva } \\
\text { João Aderson Flores } \\
\text { Antônio H. Bulcão } \\
\text { Vianna }\end{array}$ & $\begin{array}{l}\text { PPB } \\
\text { PSL } \\
\text { PPB } \\
\text { PFL } \\
\text { PFL } \\
\text { PFL }\end{array}$ & mais \\
\hline $\begin{array}{l}\text { 2) LEI COM. PMF } \\
148 / 2004\end{array}$ & $\begin{array}{c}\text { Gean Marques Loureiro } \\
\text { João da Bega } \\
\text { Juarez Silveira } \\
\text { Jaime Tonello } \\
\text { Erádio M. Gonçalves } \\
\text { João Batista Nunes } \\
\end{array}$ & $\begin{array}{l}\text { PSDB } \\
\text { PMDB } \\
\text { PFL/PPB } \\
\text { PSL/PFL } \\
\text { PSL/PFL } \\
\text { PSL/PFL } \\
\end{array}$ & mais \\
\hline $\begin{array}{l}\text { 3) LEI COM. PMF } \\
181 / 2005\end{array}$ & $\begin{array}{c}\text { Oscar Manoel Conceição } \\
\text { João Bittencourt } \\
\text { João da Bega } \\
\text { Dalmo Menezes } \\
\text { Antônio H. Bulcão } \\
\text { Vianna } \\
\text { Marcílio Ávila } \\
\end{array}$ & $\begin{array}{c}\text { PPB } \\
\text { PSL } \\
\text { PMDB } \\
\text { PP } \\
\text { PFL } \\
\text { PP }\end{array}$ & menos \\
\hline $\begin{array}{l}\text { 4) LEI COM. PMF } \\
181 / 2005\end{array}$ & Repete & Repete & menos \\
\hline $\begin{array}{l}\text { 5) LEI COM. PMF } \\
246 / 2006\end{array}$ & $\begin{array}{c}\text { João Aurélio Valente Jr. } \\
\text { João da Bega } \\
\text { Dalmo D. Menezes } \\
\text { Juarez Silveira } \\
\text { Jaime Tonello }\end{array}$ & $\begin{array}{c}\text { PP } \\
\text { PMDB } \\
\text { PP } \\
\text { PP } \\
\text { PFL }\end{array}$ & menos \\
\hline $\begin{array}{l}\text { 6) LEI COM. PMF } \\
247 / 2006\end{array}$ & $\begin{array}{l}\text { Jaime Tonello } \\
\text { Ângela Albino } \\
\text { Deglaber Goulart }\end{array}$ & $\begin{array}{c}\text { PFL } \\
\text { PCdoB } \\
\text { PSDB }\end{array}$ & menos \\
\hline $\begin{array}{l}\text { 7) LEI COM. PMF } \\
\text { 265/2007 }\end{array}$ & $\begin{array}{l}\text { João Batista Nunes } \\
\text { João da Bega } \\
\text { João Aurélio V. Jr. } \\
\text { Jaime Tonello } \\
\text { Oscar Manoel da } \\
\text { Conceição } \\
\end{array}$ & $\begin{array}{l}\text { PFL } \\
\text { PMDB } \\
\text { PP } \\
\text { PFL } \\
\text { PP }\end{array}$ & menos \\
\hline $\begin{array}{l}\text { 8) LEI COM. PMF } \\
287 / 2007\end{array}$ & $\begin{array}{l}\text { Oscar Manoel da } \\
\text { Conceição } \\
\text { João Batista Nunes } \\
\text { Juarez da Silveira } \\
\text { Dalmo Meneses } \\
\text { Alexandre Fontes } \\
\end{array}$ & $\begin{array}{l}\text { PP } \\
\text { PFL } \\
\text { PP } \\
\text { PP } \\
\text { PP }\end{array}$ & mais \\
\hline $\begin{array}{l}\text { 9) LEI COM. PMF } \\
314 / 2008\end{array}$ & Dario Berger & PMDB & não altera \\
\hline $\begin{array}{l}\text { 10) LEI COM. } \\
\text { CMF } 047 / 2002\end{array}$ & $\begin{array}{l}\text { João A. Telles } \\
\text { Bitencourt } \\
\text { Juarez Silveira } \\
\text { Ptolomeu Bittencourt Jr. } \\
\text { Jaime Tonello } \\
\text { Dalmo } \\
\text { Meneses } \\
\text { Heriberto B. Ramos Jr. } \\
\end{array}$ & $\begin{array}{c}\text { PFL } \\
\text { PFL/PPB } \\
\text { PFL } \\
\text { PSL/PFL } \\
\text { PPB } \\
\text { PFL }\end{array}$ & não altera \\
\hline
\end{tabular}




\begin{tabular}{|c|c|c|c|}
\hline $\mathrm{N}^{\circ}$ da Lei & $\begin{array}{c}\text { Políticos que assinaram } \\
\text { Lei }\end{array}$ & $\begin{array}{l}\text { Partido } \\
\text { Político }\end{array}$ & $\begin{array}{l}\text { Lei mais ou menos } \\
\text { restritiva }\end{array}$ \\
\hline $\begin{array}{l}\text { 11) LEI COM. } \\
\text { CMF 047/2002 }\end{array}$ & Repete & Repete & menos \\
\hline $\begin{array}{l}\text { 12) } \text { LEI COM. } \\
\text { CMF } 047 / 2002\end{array}$ & Repete & Repete & menos \\
\hline $\begin{array}{l}\text { 13) LEI COM. } \\
\text { CMF 047/2002 }\end{array}$ & Repete & Repete & mais \\
\hline $\begin{array}{l}\text { 14) LEI COM. } \\
\text { CMF } 047 / 2002\end{array}$ & Repete & Repete & menos \\
\hline $\begin{array}{l}\text { 15) LEI COM. } \\
\text { CMF 076/2004 }\end{array}$ & $\begin{array}{l}\text { D. J. Machado } \\
\text { Dalmo Meses } \\
\text { Juarez Silveira } \\
\text { João Aderson Flores } \\
\text { Ptolomeu B. Junior } \\
\text { Oscar Manoel da } \\
\text { Conceição } \\
\text { Antônio H. Bulcão } \\
\text { Vianna }\end{array}$ & $\begin{array}{l}\text { PPB } \\
\text { PPB } \\
\text { PFL/PPB } \\
\text { PFL } \\
\text { PFL } \\
\text { PPB } \\
\text { PFL }\end{array}$ & não altera \\
\hline
\end{tabular}

Fonte: as autoras (2017), com base na pesquisa em arquivos da Câmara Municipal de Florianópolis.

Como se pode ver, foram raras as alterações que contaram com a participação de políticos ligados aos partidos de centro e de esquerda. Entretanto, é razoável que se reconheça que mudanças isoladas no Plano Diretor tendem a resolver questões mais pontuais, entre elas os interesses da construção civil, na medida em que, no bairro estudado, o aumento da área construída para além do Plano Diretor, que já era bem permissivo, é acachapante. O adensamento do bairro gera problemas de diversas ordens: ambientais, por exemplo, mas neste caso, sobretudo de mobilidade urbana, cujo trânsito tem ficado cada dia mais caótico.

\section{Considerações Finais}

Com base no exposto, traçaram-se algumas ponderações que os dados permitem aferir. No contexto de grande crescimento urbano da cidade de Florianópolis, o bairro Itacorubi tem se apresentado como fronteira de expansão da região central da cidade. Esse crescimento foi estimulado por instituições públicas que se instalaram, trazendo consigo enormes mudanças no bairro.

A hipótese inicial desta pesquisa baseava-se na premissa de que as alterações de zoneamento ocorridas depois da instituição do Plano Diretor de 1997 teriam sido responsáveis pelo enorme crescimento desordenado do bairro. Essa suspeita não se confirmou, ou melhor dizendo, não explica sozinha todas as mazelas produzidas no Itacorubi. 
Constatou-se que o próprio Plano Diretor de 1997 foi muito permissivo, produzindo grande adensamento populacional, estimulado pela presença de empresas públicas concentradoras de empregos (Epagri, CELESC, CIDASC, CASAN) e serviços (UDESC e UFSC) e pela implantação de rodovias de acesso. À essa circunstância acrescente-se ainda menos restrições em relação ao zoneamento e tem-se a "gota d'água" que faltava para o "boom" urbano.

Em relação às alterações isoladas de partes do Plano Diretor, estima-se que estas estimulem cultura política pautada em fins individuais e privados, em detrimento de interesses coletivos e/ou públicos, impulsionando a valorização do solo em locais específicos e a produção desigual do espaço urbano.

Entende-se, portanto, que as alterações do Plano Diretor quando se banalizam, contribuem para descrédito da população nas instituições públicas de planejamento e gestão urbanas. Tal prática cultural e política origina situações como a descrita por Flávio Villaça em que "há leis que pegam e outras que não pegam", referindo-se ao cumprimento das leis no Brasil.

A fiscalização do Plano Diretor de Florianópolis deveria ser mais rígida quanto a aspectos ambientais (com estudos de impactos feitos por órgãos competentes) e quanto ao cumprimento do zoneamento determinado no Plano Diretor, pois neste caso ficaria menos suscetível a brechas de setores mais "políticos" como a Câmara dos Vereadores, o IPUF e a SUSP.

As alterações de zoneamento no bairro Itacorubi se relacionam, em sua maioria, a interesses privados e do capital imobiliário local. A prova disso é a intensa verticalização do bairro após a aprovação do Plano Diretor do Distrito Sede em 1997. Uma observação de campo não averiguada neste estudo diz respeito à pequena quantidade de empresas construtoras; sua correta identificação, avaliação e dinâmica das áreas de atuação ficam aqui como sugestões de pesquisas futuras.

Os dados apontam uma predominância de partidos de direita ou de centro na solicitação e aprovação de Leis que alteraram o zoneamento do bairro Itacorubi. Essas alterações foram, na maioria, ainda menos restritivas; permitindo o aumento das áreas construídas e o adensamento em pouquíssimo tempo. Um estudo mais aprofundado dos 
agentes modeladores do espaço urbano envolvidos com tais representações políticas também integra tema de pesquisas futuras.

\section{Referencias Bibliográficas}

BEVILACQUA, Viviane. "Maioria dos imóveis é irregular". Diário Catarinense, Florianópolis, 06 mai. 2007. Reportagem especial, p. 8.

BINOTTO Gelson Afonso (1994), O Estado e a Política Habitacional: um estudo da região conurbada de Florianópolis no período 1964-1992, Dissertação de Mestrado em Administração (Área de Concentração: Políticas e Planejamento Governamental), Universidade Federal de Santa Catarina, Florianópolis.

BORTOLUZZI, Silvia Delpizzo. UNIVERSIDADE FEDERAL DE SANTA CATARINA Programa de Pós-Graduação em Engenharia Civil. Caracterização das funções e padrões de uso e ocupação do solo no centro de Florianópolis (SC). Florianópolis, 2004. 1 v. Dissertação (Mestrado) - Universidade Federal de Santa Catarina, Centro Tecnológico. Programa de Pós-Graduação em Engenharia Civil.

BRASIL. Lei 10.257, de 10 de julho de 2001. Regulamenta os arts. 182 e 183 da Constituição Federal, estabelece diretrizes gerais da política urbana e dá outras providências. [online] Disponível em: http://www.planalto.gov.br/ccivil_03/LEIS/LEIS_2001/L10257.htm.

CARREIRÃO, Yan de Souza. Ideologia e partidos políticos: um estudo sobre coligações em Santa Catarina. Opinião Pública (UNICAMP. Impresso), Campinas, v. 12, n.1, p. 136163, 2006. Acessado em 24/10/2017.

CORREA, Roberto Lobato. O espaço urbano. São Paulo: Ática, 1989. 94p.

CAVALAZZI, João. Juarez volta a ser vereador. Diário Catarinense. [online] Disponível em:http://www.clicrbs.com.br/diariocatarinense/jsp/default2.jsp?uf=2\&local=18\&source=a19 60326.xml\&template=3898.dwt\&edition=10048\&section=213. Acesso em 19 jul. 2008, 19:49.

CAVALAZZI, João. PEREIRA, Felipe. Polícia revela como investigou suspeitos. Diário Catarinense, Florianópolis, 31 mai. 2007. Reportagem especial, p. 4-6.

DIAS, Vera L. N., NASCIMENTO, Júlio Ettore, MORESCO, Gustavo e DALLA NORA, Cristina Maria. Cadernos do Observatório Geográfico da Grande Florianópolis do PET Geografia UDESC, Volume 2, Editora Insular, Florianópolis, 2013, o artigo intitulado A Construção Imobiliária em Florianópolis e as Leis de Regulamentação: Os Planos Diretores: uma colcha de retalhos desintegrada e desintegradora.

FERNANDEZ, João Alberto da Costa Ganzo (1999), Preferências Quanto à Localização e Influência do Ciclo de Vida Familiar: estudo exploratório com moradores de apartamentos do centro de Florianópolis, Dissertação de Mestrado em Engenharia Civil, Florianópolis, Universidade Federal de Santa Catarina.

FLORIANÓPOLIS (SC). Lei 1516 de 25 de junho de 1977. DISCIPLINA O USO DO SOLO, DISPÕE SOBRE ÁREAS VERDES, EQUIPAMENTOS URBANOS E DÁ OUTRAS PROVIDÊNCIAS. [online] Disponível em: http://sistemas.sc.gov.br/cmf/pesquisa/docs/1977/lpmf/lei1516_77.doc. Acesso em 21 jul. 2008.

FLORIANÓPOLIS (SC). Lei Complementar 001 de 18 de fevereiro de 1997. DISPÕE SOBRE O ZONEAMENTO, O USO E OCUPAÇÃO DO SOLO NO DISTRITO SEDE DE FLORIANÓPOLIS E DÁ OUTRAS PROVIDÊNCIAS. [online] Disponível em: 
http://sistemas.sc.gov.br/cmf/pesquisa/docs/1997/lcpmf/leicom001_97.doc. Acesso em 21 jul. 2008.

FLORIANÓPOLIS (SC) Política Habitacional de Florianópolis. Gestão 2000-2004. Trabalho elaborado com apoio do Programa Habitar Brasil/BID,CAIXA e Secretaria Especial de Desenvolvimento Urbano da Presidência da República. Versão preliminar fevereiro de 2002.

INSTITUTO DE PLANEJAMENTO URBANO DE FLORIANÓPOLIS. Aplicação da sistemática dos condicionantes, deficiência e potencialidades (CDP) ao planejamento do uso do solo urbano: a experiência da prefeitura municipal de Florianópolis. Prefeitura de Florianópolis, [19--].

MIRANDA Rogério, (2001), Habitação Popular e Favelas: em Biguaçu, Florianópolis, Palhoça e São José, Mimeo, Florianópolis, outubro.

NEUMANN Clóvis (1998), O Processo de Intensificação Urbana do Centro de Florianópolis, Dissertação de Mestrado em Engenharia Civil, Universidade Federal de Santa Catarina, Florianópolis.

NEUMANN, Clóvis; JUNGLES, Antonio Edesio. UNIVERSIDADE FEDERAL DE SANTA CATARINA Centro Tecnológico. O processo de intensificação urbana do centro de Florianópolis. Florianópolis, 1998. 186 f. Dissertação (Mestrado) - Universidade Federal de Santa Catarina, Centro Tecnológico.

PEREIRA, Felipe. "Polícia Federal prende 19 empresários e políticos". Diário Catarinense, Florianópolis, 04 mai. 2007. Reportagem especial, p. 4.

RIZZO, Paulo Marcos Borges; SOSTISSO, Ivo. UNIVERSIDADE FEDERAL DE SANTA CATARINA Centro de Filosofia e Ciências Humanas. Do urbanismo ao planejamento urbano: utopia e ideologia : caso de Florianópolis, 1950 a 1990. 1993. 119f. Dissertação (Mestrado) - Universidade Federal de Santa Catarina. Centro de Ciências Humanas.

ROLNIK, Raquel. Estatuto da Cidade - Instrumento para as cidades que sonham crescer com justiça e beleza. Disponível em: http://www.estatutodacidade.org.br/estatuto/artigo1.html. Acesso em: 22 jun. 2007.

Recebido em 28 de outubro de 2017.

Aceito em 20 de fevereiro de 2018. 